\title{
The Effect Of Financial Literacy, Fintech (Financial Technology) and Intellectual Capital On The Performance Of MSMEs In Depok City, West Java
}

\author{
Nur Hamidah, Rida Prihatni, IGKA Ulupui \\ State University of Jakarta, Indonesia \\ State University of Jakarta, Indonesia \\ State University of Jakarta, Indonesia \\ Email:hamidahnur94@gmail.com
}

\section{ARTICLE INFO}

Date received:

Revision date : 25 August 2020

Date received :

Keywords:

Loans

Problematic Loans

Unit Pengelola Kegiata

Sharia

\begin{abstract}
MSMEs are growing and competing in a business environment that is constantly changing like today in the digital era, it is necessary to monitor and understand company performance to achieve a greater level of business than before, and to determine the extent to which business is being carried out on target. This study aims to analyze and examine the effect of financial literacy, fintech (financial technology), and intellectual capital on the performance of MSMEs in Depok City. Determination of the sample using probability sampling with a proportional random sampling technique than simple random sampling. The number of samples used was 286 samples. The primary data source was taken by using a survey method with a questionnaire. The research design used descriptive and parametric statistical analysis methods with instrument tests and multiple linear regression analysis. The results of this study are financial literacy, fintech (financial technology) and intellectual capital have a positive and significant effect on the performance of MSMEs in Depok City .
\end{abstract}

\section{INTRODUCTION}

As a driving force for socio-economic development in all countries, micro, small and medium enterprises (MSMEs) are newly developing productive enterprises and the forerunners of large enterprises in the future that are owned by individuals and business entities. Since the economic crisis in the 1990s, it has shown that micro, small and medium enterprises continue to grow and become saviors by contributing to GDP and employment. The development of SMEs is consistently the government's top priority because it is considered to be able to provide benefits for social welfare (Anas, Mangunsong, and Panjaitan, 2017).
In addition to the advantages of MSMEs in Indonesia which can provide a large GDP contribution to the country and can absorb labor, MSMEs in Indonesia also have several weaknesses including lack of financial stability in access to capital, lack of resources to use advanced technology, and have not evaluated management performance. relevant for analysis and facing challenges (Zulkifli, Char, Rushdan and Hassan, 2010).

Depok City is one of the cities in West Java which is quite advanced with a population in 2017 of 2 million. The growth of Micro Small Enterprises and Large Medium Enterprises is the largest in Bandung City and then Bekasi (Dinas Koperasi dan Usaha 
Kecil Jabar, 2017), this shows that the growth of MSMEs in Depok City is still very far away so it needs to be maximized because Depok is a a large and developing city.

The growth of micro, small and medium enterprises can be measured quantitatively and qualitatively. Qualitative growth can be achieved through subjective company attributes such as increasing the quality of output and describing a positive image of the product. A quantitative perspective is also considered which can be observed in measurable indicators such as an increase in the number of employees, sales revenue and profitability (Anderson, 2017).

Data from the OJK (Otorisasi Jasa Keuangan) states that around $60 \%$ have bank accounts. This number is far behind Malaysia, which reached $81 \%$ and China 79\% (Global Findex, 2017). These obstacles occur due to a lack of understanding of financial literacy. For this reason, efforts are needed to educate MSME owners or managers to provide knowledge, attitudes and awareness to overcome and direct their organization's finances in a strong, transparent and professional way (Karen, 2010).

The advancement of information technology in the era of the industrial revolution 4.0 currently has many benefits through the innovations produced. Among them are the benefits of digital fintech technology (financial technology). Most of the information technology in an organization aims to be able to make a positive contribution to the individual performance of members of the organization and its institutions (Brynjolfsson and Hitt, 1996). Technology contributing to performance must be supported by an understanding for managers to understand the use of the system (Lucas and Spitler, 1999).

An MSMEs certainly has optimism for its growing business, so that MSMEs players try to improve their future-oriented business through competitive advantages, entrepreneurs must have an understanding of financial literacy and take advantage of technology as the times and utilize intellectual capital. Intellectual capital is a company resource that can be developed including land, technology, labor (ability and knowledge), capital, and legacy of expertise (Leitner, 2011).

\section{THEORITICAL FRAMEWORK AND HYPOTHESIS}

\section{The Financial Literacy And Performance}

Tuffour, Amoako, and Amartey (2020) in measuring financial literacy which consists of financial knowledge, awareness, and financial attitudes among SME entrepreneurs in Ghana has an influence on financial and non-financial performance.
In the research of (Sanistasya, Rahardjo, and Iqbal, 2019) financial literacy is considered capable of facilitating small businesses to expand and increase profitability, productivity, and competitive advantage. Financial literacy in its application is an important component in the organization, with financial literacy will increase understanding of management practices and minimize losses so as to increase the sustainability of SMEs ( $\mathrm{Ye}$ and Kulathunga, 2019). Research by Sabana, (2014) concluded that financial literacy will increase the importance of decision-making from SME financial management including financial planning, cash flow management, and reliable financial reports. Based on this description, the following research hypothesis is formulated:

\section{H1: Financial literacy has a positive effect on performance}

\section{The Fintech (Financial Technology) And Performance}

The application of technology-based finance to company performance uses individual perceptions, namely business actors and managers. Research (Onyango, Ongus, Awuor, and Nyamboga, 2014) shows that there is an effect of technology adoption and use on the performance of MSMEs because according to business actors or managers who use technology, in terms of costs and impacts in daily activities that increase efficiency.

Besides, in the research on technology adoption in MSMEs researched by (Infithor and Kornitasari, 2019), it found that information technology affected expectations of increased performance. Business owners find information technology helpful in completing their tasks. So that the application of technology can be said to have an impact on the productivity of the process will expand sales, improve customer service, and provide a competitive position (Endraswari, 2006). Based on this description, the following research hypothesis is formulated:

\section{H2: Fintech has a positive effect on performance}

\section{The Intellectual Capital and Performance}

Broad recognition that intellectual capital is a critical force that drives economic growth (Dewi, Alhabsyi, Arifin, and Abdillah, 2019). Intellectual capital in micro, small, and medium enterprises (MSMEs) can help entrepreneurs better understand the importance of capitalizing on intangible assets to create competitiveness in the market (Khalique, Bontis, Shaari, Yaacob, and Ngah, 2018).

(Supeno, Sudharma, Aisjah, and Laksmana, 2015) examine that intellectual capital creates a competitive advantage between the competition between the same MSMEs business industries in 
organizational performance because it is considered a strategic resource that must be owned by MSMEs.

Intellectual capital research indicates that

intellectual capital developed in honing competent employees, innovating, and maintaining good relationships will result in successful businesses in

the future and can excel in business competition between entrepreneurs in similar fields (Absah, Chairunisa Muchtar, and Qamariah, 2018).

H3: Intellectual capital has a positive effect on performance

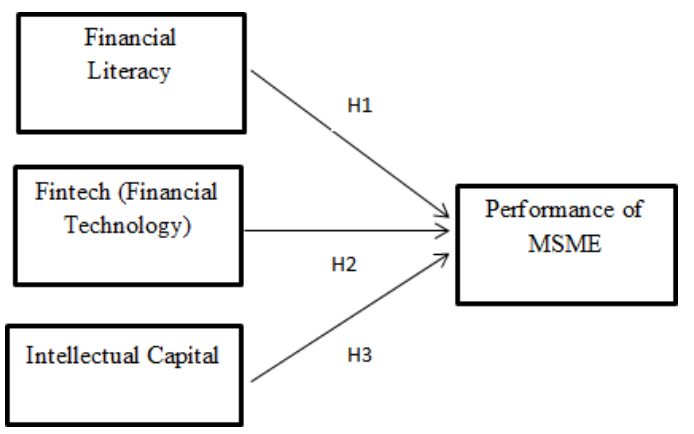

Figure 1. Theoritical Framework

\section{METODE}

The type of research used in this study uses a quantitative approach. The method in this study uses primary data sources from direct distribution of questionnaires and via google form which is distributed to social media WhatsApp, Depok UMKM Facebook group, and email to owners of MSMEs. The research method used descriptive and parametric statistical analysis with the analysis technique of instrument test, basic assumption test, and hypothesis testing using SPSS version 22 .

\section{Population and Sample}

The population of this research is the owners of micro, small and medium enterprises (MSMEs) in Depok. The sample size was taken using the slovin formula and the number of samples used was 286 samples. Determination of the sample using probability sampling with a proportional random sampling technique than simple random sampling.

The variables in this study consisted of independent variables (independent) and dependent variables (dependent). The independent variables in this study are Financial Literacy (X1), Fintech (X2), Intellectual Capital (X3), and the dependent variable is Performance $(Y)$.

\section{RESULTS AND DISCUSSION ANALYSIS Validity Test of Items Financial Literacy}

\begin{tabular}{|l|r|r|r|r|}
\hline & $\begin{array}{c}\text { Scale } \\
\text { Mean if } \\
\text { Item } \\
\text { Deleted }\end{array}$ & $\begin{array}{c}\text { Scale } \\
\text { Variance if } \\
\text { Item } \\
\text { Deleted }\end{array}$ & $\begin{array}{r}\text { Corrected } \\
\text { Item-Total } \\
\text { Correlation }\end{array}$ & $\begin{array}{c}\text { Cronbach's } \\
\text { Alpha if } \\
\text { Item } \\
\text { Deleted }\end{array}$ \\
\hline q1 & 47,43 & 69,840 &, 650 &, 888 \\
q2 & 47,37 & 71,895 &, 541 &, 893 \\
q3 & 47,33 & 73,402 &, 550 &, 892 \\
q4 & 47,37 & 69,344 &, 628 &, 889 \\
q5 & 47,23 & 69,978 &, 607 &, 890 \\
q6 & 47,37 & 71,895 &, 541 &, 893 \\
q7 & 47,23 & 69,978 &, 607 &, 890 \\
q8 & 47,13 & 74,326 &, 462 &, 896 \\
q9 & 47,23 & 69,978 &, 607 &, 890 \\
q10 & 47,33 & 70,161 &, 610 &, 889 \\
q11 & 47,37 & 70,723 &, 636 &, 888 \\
q12 & 47,27 & 71,444 &, 623 &, 889 \\
q13 & 47,13 & 69,016 &, 729 &, 884 \\
\hline
\end{tabular}

Based on the table above to determine whether the item is valid or not by comparing $r$ count (value on Corrected Item total correlation) with $r$ table. $r$ table looking for a significance of 0.05 with a 2-sided test and $\mathrm{N}=30 / \mathrm{df}=28$, then the $r$ table is obtained is 0.3610 . From the output of the corrected item correlation value $\geq 0.3610$, it can be concluded that 13 items of financial literacy are said to be valid.

\section{Validity Test of Items Fintech}

Item-Total Statistics

\begin{tabular}{|r|r|r|r|r|}
\hline & $\begin{array}{c}\text { Scale } \\
\text { Mean if } \\
\text { Item } \\
\text { Deleted }\end{array}$ & $\begin{array}{c}\text { Scale } \\
\text { Variance if } \\
\text { Item } \\
\text { Deleted }\end{array}$ & $\begin{array}{c}\text { Cronbach' } \\
\text { Corrected } \\
\text { Item-Total } \\
\text { Correlation }\end{array}$ & $\begin{array}{c}\text { Alpha if } \\
\text { Item } \\
\text { Deleted }\end{array}$ \\
\hline q1 & 7,80 & 2,234 &, 691 &, 741 \\
q2 & 7,60 & 2,317 &, 604 &, 821 \\
q3 & 7,80 & 1,821 &, 744 &, 682 \\
\hline
\end{tabular}

Based on the table above to determine whether the item is valid or not by comparing $r$ count (value on Corrected Item total correlation) with $r$ table. $r$ table looking for a significance of 0.05 with a 2-sided test and $\mathrm{N}=30 / \mathrm{df}=28$, then the $r$ table is obtained is 0.3610 . From the output of the corrected item correlation value $\geq 0.3610$, it can be concluded that 3 fintech items are said to be valid.

\section{Validity Test of Items Intellectual Capital Item-Total Statistics}

\begin{tabular}{|l|r|r|r|r|}
\hline & $\begin{array}{c}\text { Scale } \\
\text { Mean if } \\
\text { Item } \\
\text { Deleted }\end{array}$ & $\begin{array}{c}\text { Scale } \\
\text { Variance if } \\
\text { Item } \\
\text { Deleted }\end{array}$ & $\begin{array}{r}\text { Corrected } \\
\text { Item-Total } \\
\text { Correlation }\end{array}$ & $\begin{array}{c}\text { Cronbach' } \\
\text { s Alpha if } \\
\text { Item } \\
\text { Deleted }\end{array}$ \\
\hline q1 & 37,47 & 20,947 &, 601 &, 844 \\
q2 & 37,47 & 21,361 &, 578 &, 846 \\
q3 & 37,07 & 23,168 &, 621 &, 842 \\
q4 & 37,43 & 21,151 &, 618 &, 842
\end{tabular}




\begin{tabular}{|l|l|l|r|r} 
q5 & 37,43 & 22,806 &, 571 &, 845 \\
q6 & 37,07 & 24,340 &, 387 &, 859 \\
q7 & 37,27 & 22,409 &, 619 &, 841 \\
q8 & 37,13 & 23,844 &, 592 &, 846 \\
q9 & 37,23 & 23,426 &, 592 &, 845 \\
q10 & 37,03 & 23,275 &, 595 &, 844 \\
\hline
\end{tabular}

Based on the table above to determine whether the item is valid or not by comparing $r$ count (value on Corrected Item total correlation) with $r$ table. $r$ table looking for a significance of 0.05 with a 2-sided test and $\mathrm{N}=30 / \mathrm{df}=28$, then the $\mathrm{r}$ table is obtained is 0.3610 . From the output value of the corrected item correlation $\geq 0.3610$, it can be concluded that 10 items of intellectual capital are said to be valid

\section{Validity Test Of Items Performance}

\begin{tabular}{|l|r|r|r|r|}
\hline & $\begin{array}{c}\text { Scale } \\
\text { Mean if } \\
\text { Item } \\
\text { Deleted }\end{array}$ & $\begin{array}{c}\text { Scale } \\
\text { Variance if } \\
\text { Item } \\
\text { Deleted }\end{array}$ & $\begin{array}{c}\text { Cronba } \\
\text { Corrected } \\
\text { Item-Total } \\
\text { Correlation }\end{array}$ & $\begin{array}{c}\text { Ch's } \\
\text { Alpha if } \\
\text { Item } \\
\text { Deleted }\end{array}$ \\
\hline q1 & 26,07 & 20,892 &, 763 &, 869 \\
q2 & 26,13 & 21,292 &, 707 &, 875 \\
q3 & 26,00 & 20,828 &, 702 &, 876 \\
q4 & 25,67 & 22,161 &, 619 &, 884 \\
q5 & 26,03 & 21,344 &, 666 &, 879 \\
q6 & 25,60 & 24,938 &, 459 &, 896 \\
q7 & 26,07 & 20,892 &, 763 &, 869 \\
q8 & 25,63 & 21,620 &, 672 &, 879 \\
\hline
\end{tabular}

Based on the table above to determine whether the item is valid or not by comparing $r$ count (value on Corrected Item total correlation) with $r$ table. $r$ table looking for a significance of 0.05 with a 2-sided test and $\mathrm{N}=30 / \mathrm{df}=28$, then the $r$ table is obtained is 0.3610 . From the output of the corrected item correlation value $\geq 0.3610$, it can be concluded that 8 performance items are said to be valid.

\section{Reliability Test}

\begin{tabular}{|c|c|c|c|}
\hline Variabel & $\begin{array}{c}\text { Alpha } \\
\text { Cronbach }\end{array}$ & $\begin{array}{c}\text { CR } \\
\text { Tabl } \\
\mathbf{e}\end{array}$ & $\begin{array}{c}\text { Conclus } \\
\text { ions }\end{array}$ \\
\hline $\begin{array}{c}\text { Financial } \\
\text { Literacy }\end{array}$ & 0,89 & 0,60 & Reliable \\
\hline Fintech & 0,82 & 0,60 & Reliable \\
\hline $\begin{array}{c}\text { Intellectual } \\
\text { Capital }\end{array}$ & 0,86 & 0,60 & Reliable \\
\hline Performance & 0,89 & 0,60 & Reliable \\
\hline
\end{tabular}

Source : Process data (2020)

Based on the table above, it can be concluded that all variables have a Cronbach Alpha that is greater than 0.60 so that these variables are declared worthy of being used as a data collection instrument.
The results of the validity and reliability testing that have been described, it can be concluded that all statements used in this study have been tested for validity and reliability so that all statements are feasible to be used as research measurements.

Multiple Linier Regression Analysis ANOVA $^{\mathrm{a}}$

\begin{tabular}{|l|c|r|r|r|r|}
\hline Model & Sum of & Mean & F & Sig. \\
\hline Squares & df & Square & F & Regression \\
\hline Residual & 2190,205 & 3 & 730,068 & 97,999 &, $000^{\circ}$ \\
Total & 2100,829 & 282 & 7,450 & & \\
\hline
\end{tabular}

a. Dependent Variable: Performance $(\mathrm{Y})$

b. Predictors: (Constant), Intellectual Capital

(X3), Fintech (Financial Technology) (X2),

Finnacial Literacy (X1)

\begin{tabular}{|c|c|c|c|c|c|}
\hline \multirow[b]{2}{*}{ Model } & \multicolumn{2}{|c|}{$\begin{array}{l}\text { Unstandardiz } \\
\text { ed } \\
\text { Coefficients }\end{array}$} & \multirow{2}{*}{$\begin{array}{c}\begin{array}{c}\text { Standardi } \\
\text { zed } \\
\text { Coefficien } \\
\text { ts }\end{array} \\
\text { Beta }\end{array}$} & \multirow[b]{2}{*}{$\mathrm{t}$} & \multirow[b]{2}{*}{ Sig. } \\
\hline & B & $\begin{array}{l}\text { Std. } \\
\text { Error }\end{array}$ & & & \\
\hline (Constant) & 4,129 & 1,703 & & 2,424 & ,016 \\
\hline $\begin{array}{l}\text { Financial Literacy } \\
\text { (X1) }\end{array}$ &, 146 & ,024 & ,285 & 6,020 & ,000 \\
\hline $\begin{array}{l}\text { Fintech (Financial } \\
\text { Literacy) (X2) }\end{array}$ & ,649 &, 095 & ,318 & 6,829 & ,000 \\
\hline $\begin{array}{l}\text { Intellectual } \\
\text { Capital (X3) }\end{array}$ & ,295 &, 044 & ,322 & 6,714 &, 000 \\
\hline
\end{tabular}

a. Dependent Variable: Performance (Y)

Model Summaryb

\begin{tabular}{|l|l|r|r|r|}
\hline Model & $\mathrm{R}$ & $\mathrm{R}$ Square & $\begin{array}{c}\text { Adjusted R } \\
\text { Square }\end{array}$ & $\begin{array}{c}\text { Std. Error of } \\
\text { the Estimate }\end{array}$ \\
\hline 1 &, $714^{a}$ &, 510 &, 505 & 2,729 \\
\hline
\end{tabular}

a. Predictors: (Constant), Intellectual Capital (X3), Fintech

(Financial Technology) (X2), Finnacial Literacy (X1)

b. Dependent Variable: Performance (Y)

It is found the Multiple Regression Analysis Model is :

$$
\mathrm{Y}=4,129+0.146 \mathrm{LK}+0,649 \mathrm{FT}+0,295 \mathrm{MI}+\mathrm{e} .
$$

From the table above shows 3 predictive variables, LK (Sig. $=0,000)$, FT (sig. $=0,000)$ and $\mathrm{MI}$ (Sig. = 0,000) significantly affect the performance of MSMEs. The coefficient of determination (R2) in this study is the amount of the coefficient of determination in this study is 0.510 , so it can be concluded that financial literacy, fintech, and intellectual capital contribute $51 \%$ of MSMEs performance. While the remaining $49 \%$ is explained by other variables outside the model.

\section{Analysis of Research Hypotheses}

1. Effect Financial Literacy on Performances of MSME

In table multiple regression analysis the coefficient value of the financial literacy, a variable is 0.146 and sig. 0,000 and $\mathrm{H} 1$ is 
acceptable, it can be concluded that financial literacy has a positive and significant effect on the performance of MSMEs.

This research is in line with the research conducted (Tuffour et al., 2020), (Sanistasya et al., 2019), (Ye and Kulathunga, 2019) and (Sabana, 2014) stated that financial literacy has a positive influence on MSMEs performance. So that financial literacy plays the role of MSMEs in performance to control the future by adapting to rapid economic changes in the business environment in making more protective decisions.

\section{Effect Fintech (Financial Literacy) on Performances of MSME}

In table multiple regression analysis the value of the regression coefficient of the fintech variable (financial technology) is 0.649 and Sig. 0,000 , it can be concluded that fintech (technology-based finance) has a positive and significant effect on the performance of MSMEs.

Fintech is considered to provide convenience for business support because it is more effective and efficient and the application

is easy to obtain. Besides, the adoption of fintech can consumers with various promotions and delivery services that have an increasing impact on their business. Another consideration is the transparency of the history of incoming money, and it does not rule out the possibility of fintech being used for payment of transactions for their business activities.

This research is in line with research (Infithor and Kornitasari, 2019) (Infithor and Kornitasari, 2019), (Onyango et al., 2014) and (Endraswari, 2006) that technology can improve the performance of an organization. The application of this new culture opens opportunities for comfort between business owners and consumers because it is faster and can reach a wider market.

\section{Effect Intellectual Capital Performances of MSME}

In table multiple regression analysis the coefficient value of the intellectual capital, a variable is 0.295 and Sig. 0.000 , it can be concluded that intellectual capital has a positive and significant effect on the performance of MSMEs.

This is in line with research on intellectual capital in MSMEs conducted by (Dewi et al., 2019), (Absah et al., 2018), (Khalique et al., 2018) and (Supeno et al., 2015) that intellectual capital includes human capital, structural capital and customer capital to create a competitive advantage among the competition between the same MSME business industry in organizational performance because it is considered a strategic resource that must be owned.

\section{Discussions}

From the results of research and variable testing, suggestions that can be given as input to the goverment can grow and increase levels include:

1. There is a need for gradual scale training for understanding financial literacy in addition to financial knowledge, knowledge of good bookkeeping can also be provided, assessing financial performance, sharpening attitudes in making decisions regarding financial products and services. It is hoped that from financial literacy, the owners of MSMEs can prepare a funding strategy for their business with good and mature decisions. Besides, financial literacy will increase financial inclusion in the stability of the country because MSMEs owners will have an economic mindset on how to view profit and money.

2. Basic introduction to various types of fintech or financial technology applications so that business actors are technology literate so that they can provide benefits, even though later there will be positive or negative values from patterns or thoughts that have not received well. The application of fintech will be a challenge for MSME owners to be able to make these services their partners. Besides, it is hoped that with technological literacy, business actors will not fall into illegal or harmful applications.

3. Providing innovative and creative MSME development by opening collaborations or partnerships with large local and international companies.

Furthermore, from the results of research and variable testing, suggestions that can be given as input to business owners or MSME managers include

1. Whereas activities related to finance and technology are needed by MSMEs in the current situation.

2. Sharpening special skills to produce products and services that are unique and difficult to imitate, by providing motivation and means at work, besides maintaining good relationships with relationships (consumers and vendors) need to be maximized properly because they can affect performance.

Based on the limitations of the researcher, it is suggested for further researchers:

1. Conduct research on a more specific business industry to see its influence on that particular business industry. 
2. Adding other statements besides this research to measure more deeply the variables of financial literacy, fintech and intellectual capital.

3. Measuring the questionnaire items on a nominal scale ("yes" or "no") to confirm answers.

\section{CONCLUSION}

Based on the analysis and discussion that has been stated previously, the following conclusions can be drawn:

1. The hypothesis of the effect of financial literacy on performance, the results are positive and significant. This concludes that when financial literacy can be improved, the performance of MSMEs will also increase.

2. The hypothesis of the effect of fintech (financial technology) on performance, positive and significant results are obtained. This concludes that the use of various types of fintech applications (technology-based finance) when they can be properly improved, it can help the performance of MSMEs to get better.

3. The hypothesis of the effect of intellectual capital on performance, positive and significant results are obtained. This concludes that when intellectual capital is maximized properly, the performance of MSMEs will be good too.

\section{REFERENCES}

Absah, Y., Chairunisa Muchtar, Y., \& Qamariah, I. (2018). The Effect of Intellectual Capital on Business Performance in Micro-, Small-, and Medium Enterprise (MSME) in Medan City. $\mathrm{KnE}$ Social Sciences, 3(10), 177-186. https://doi.org/10.18502/kss.v3i10.3371

Anas, T., Mangunsong, C., \& Panjaitan, N. A. (2017). Indonesia SME Participation in ASEAN Economic Integration. Journal of Souteast Asian Economies, 34(1), 77-117. https://doi.org/10.1355/ae34-ld

Anderson, W. (2017). Factors Affecting Small \& Medium Enterprises (SMEs) Start- up and Growth in Tanzania. The Pan-African Journal of Business Management, 1(1).

Brynjolfsson, E., \& Hitt, L. (1996). Paradox Lost? Firm-level Evidence on the Returns to Information Systems Spending. (4).

Dewi, R. S., Alhabsyi, T., Arifin, Z., \& Abdillah, Y. (2019). Does Intellectual Capital Improve on The Performance of SME ' s? 22(2), 81-86.

Dinas Koperasi dan Usaha Kecil Jabar. (2017). Jumlah Usaha Menurut Kab. Kota Dan Skala Usaha di Jawa Barat.

Endraswari, R. M. (2006). Faktor-Faktor Yang Mempengaruhi Aplikasi Teknologi Informasi dan Dampaknya Terhadap Kinerja
Perusahaan (Studi pada UKM Kerajinan Tangan Bantul, Yogyakarta). Universitas Diponegoro.

Global Findex. (2017). Global Findex Database 2017: Measuring Financial Inclusion and the Fintech Revolution.

Infithor, M. F., \& Kornitasari, Y. (2019). JURNAL ILMIAH Disusun Oleh: Muhammad Falaq infithor. (145020107111014).

Karen, B. Y. (2010). S h o w Me t h e Money Resources: Financial Literacy for $21 \mathrm{st}-\mathrm{c} \mathrm{e}$ $\mathrm{n}$ t u r y Learners a r. (April), 24-28.

Khalique, M., Bontis, N., Shaari, N. . J., Yaacob, R. M., \& Ngah, R. (2018). Intellectual capital and organisational performance in Malaysian knowledge-intensive SMEs. 15(1), 20-36.

Leitner, K. H. (2011). The effect of intellectual capital on product innovativeness in SMEs. International Journal of Technology Management, $\quad 53(1), \quad 1-18$. https://doi.org/10.1504/IJTM.2011.037235

Lucas, H. C., \& Spitler, V. K. (1999). Technology Use and Performance: A Field Study of Broker Workstations *. 30(2).

Onyango, R. a, Ongus, R. W., Awuor, F. M., \& Nyamboga, C. (2014). Impact of Adoption and $U$ se of Mobile Phone Technology on the Performance of Micro and Small Enterprises in Kisii Municipality Kenya. World Journal of Computer Application and Technology, 2(2), 34-42. https://doi.org/10.13189/wjcat.2014.020202

Sabana, B. M. (2014). Enterpreneur Financial Literacy, Financial Access, Transaction Costs and Performance of Micro Enterprises In Nairobi City Country, Kenya. Thesis.

Sanistasya, P. A., Rahardjo, K., \& Iqbal, M. (2019). Pengaruh Literasi Keuangan dan Inklusi Keuangan Terhadap Kinerja Usaha Kecil di Kalimantan Timur The Effect of Financial Literacy and Financial Inclusion on Small Enterprises Performance in East Kalimantan. $14,48-59$.

Supeno, H., Sudharma, M., Aisjah, S., \& Laksmana, A. (2015). The Effects of Intellectual Capital, Strategic Flexibility, and Corporate Culture on Company Performance: A Study on Small and Micro-scaled Enterprises ( SMEs ) in Gerbangkertosusila Region , East Java. 11(1), 1-12. https://doi.org/10.3968/7200

Tuffour, J. K., Amoako, A. A., \& Amartey, E. O. (2020). Assessing the Effect of Financial Literacy Among Managers on the Performance of Small-Scale Enterprises. Global Business Review. https://doi.org/10.1177/0972150919899753 
Ye, J., \& Kulathunga, K. (2019). How Does Financial Literacy Promote Sustainability in SMEs? A Developing Country Perspective. 121.
Zulkifli, M., Char, A., Rushdan, M., \& Hassan, Z. (2010). Small and Medium Enterprises (SMEs) Competing in the Global Business Environment: A Case of Malaysia. 3(1), 6675.

\section{Copyright holder:}

Nur Hamidah, Rida Prihatni, IGKA Ulupui (2020)

First publication right :

Journal of Social Science

This article is licensed under:

(c) (i) (O) 